\title{
Productive behavior of sheep fed with soy (Glycine max L.) forage
}

\author{
Torres-Salado, N. ${ }^{1}$, García-Raymundo, Oscar D. ${ }^{2}$, Maldonado-Peralta, María A. ${ }^{1}$, Rojas-García, Adelaido R. ${ }^{1}$ \\ Ayala-Monter, Marco A. ${ }^{1^{*}}$, Sánchez-Santillán, Paulino ${ }^{1}$ \\ ${ }^{1}$ Universidad Autónoma de Guerrero, Facultad de Medicina Veterinaria y Zootecnia No. 2. \\ Cuajinicuilapa, Guerrero, México. ${ }^{2}$ Universidad Autónoma de Guerrero, Programa de Licenciatura \\ de Médico Veterinario Zootecnista, Cuajinicuilapa, Guerrero, México. \\ *Corresponding Author: maamonter@hotmail.com
}

\begin{abstract}
Objective: To evaluate the productive behavior of Creole sheep in the tropics fed a whole food diet that includes soybean (FS, Glycine max) fodder at different phenological stages

Methodology: The treatments T1: control, T2: 30\% (SF-56 d), T3: 30\% (SF-68 d), T4: 30\% (SF-85 d), T5: $30 \%$ (SF-110 d) were assigned randomly to 30 male Creole sheep (15.51 $1.6 \mathrm{~kg} \mathrm{LW})$. The experiment lasted $56 \mathrm{~d}$. The variables evaluated were: dry matter intake (DMI), daily weight gain (DWG) and feed conversion (FC). The experimental design was completely randomized and the averages of the treatments were compared using the Tukey test.

Results: Differences $(p<0.05)$ were found in DMI, DWG and FC. The DMI was lower $(p<0.05)$ in the control group. The DWG was higher in the animals that consumed soybean fodder compared to the control group $\left(0.205 \mathrm{vs} 0.121 \mathrm{~kg} \mathrm{~d}^{-1}\right)$ The FC decreased ( $p<0.05$ ) 51\% in T3 (SF 68 d), with respect to the control group

Study Limitations: The nutrient contribution of soybean fodder is based on the phenological stage of the plant. Likewise, producers in the tropical region have scarce knowledge about how to incorporate it in the feeding of small ruminants.

Conclusions: The inclusion of $30 \%$ of soybean fodder at $68 \mathrm{~d}$ of age in a whole food diet improves the productive performance of the lambs because it increases daily weight gain and decreases feed conversion.
\end{abstract}

Keywords: Glycine max, sheep, soybean fodder, tropics.

\section{INTRODUCTION}

At present the elevated cost of animal feed due to the use of grains and oilseeds drive up At Present, production costs (Khan et al., 2015) and reduce the profitability of sheep farming. In general, worldwide sheep production is developed in grazing production systems (Palma, 2005; Partida et al., 2013; Vélez et al., 2016). This situation represents an economic advantage since farmers save on animal feed production costs, and these systems generate the best cost/benefit relation and also improve the nutritional quality of the meat

Agroproductividad: Vol. 13, Núm. 12, diciembre. 2020. pp: 63-67. Recibido: abril, 2020. Aceptado: noviembre, 2020
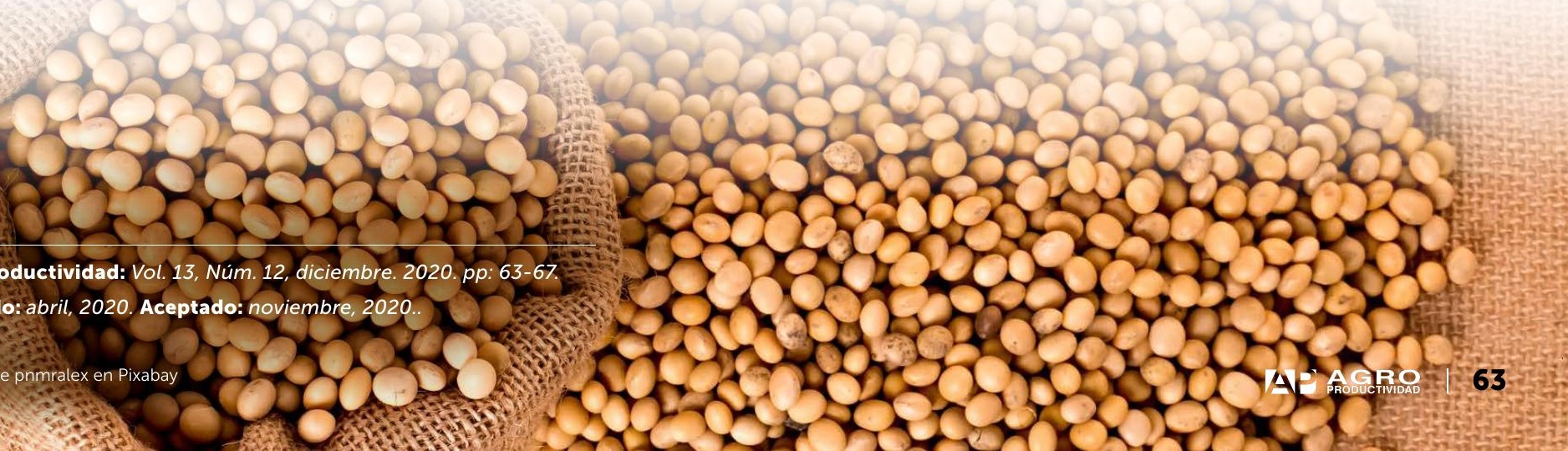
(Pirela et al., 2010). The Mexican tropics, due to their climatic, edaphic and topographic characteristics, are known for their great biological diversity in terms of natural resources such as plant, trees and fodder shrub species (Palma, 2005). These species produce fruit rich in digestible energy, protein and minerals which can be incorporated in sheep feed during the dry season (Zamora et al., 2001). These fruits are an alternative for sheep and can be used as a strategy to decrease the dependence on commercial concentrates in ruminant production systems (Garcia et al., 2008; Clavero, 2013; Delgado et al., 2014). On the other hand, soy [Glycine max (L.) Merr.] is considered a legume with forage potential due to its high production of dry matter (Tobia and Villalobos, 2004; Vargas-Bello-Pérez et al., 2008) and elevated protein content, therefore it represents an alternative to increase the protein content in the animal's diet (Dias et al., 2016). This favors a reduction in the use of protein supplements and, therefore, decreases the costs of animal feed in tropical production systems (Rigueira et al., 2015). It is important to mention that soybean fodder which produces the most seeds is the best variety, since this is the part of the plant that contains the greatest percentage of fat and protein (Tobía et al., 2006). In this sense, studies on soybean fodder (Glycine max) are centered on agronomic studies and have reported soybean fodder as a protein-energy alternative for ruminants' feed in the tropics (Tobia and Villalobos, 2004; Tobía et al., 2006; Orozco et al., 2015). In the revised literature in Mexico, there was no information on its use in in vivo studies in small ruminants. Therefore, the objective of the present study was to evaluate the productive behavior of Creole sheep in the tropics, fed with a whole food diet which included soybean (Glycine max) fodder in different phenological stages.

\section{MATERIALS AND METHODS Location}

This study was carried out in the Experimental Farm of the Agricultural Baccalaureate Center No. 102 and Animal Nutrition Laboratory of the School Veterinary Medicine and Zootechnics No. 2 of the Universidad Autónoma de Guerrero, both located in Cuajinicuilapa, Guerrero (16 $18^{\prime} 58^{\prime \prime} \mathrm{N}, 98^{\circ} 43^{\prime} 44^{\prime \prime} \mathrm{W}$, at 50 masl). The region's climate is warm sub-humid with summer rains, monsoonal rainfall, and average annual temperature of $27^{\circ} \mathrm{C}$ (CONAGUA, 2019).

\section{Animals and Management}

Thirty Creole male lambs were used $(15.51 \pm 1.6 \mathrm{~kg} L W)$, held in individual cages $\left(2 \mathrm{~m}^{2}\right)$ equipped with a feeder and drinking trough. Before the experimental phase they received prophylactic treatment with an anti-parasitic (Ivomec ${ }^{\circledR}$, Ivermectina, $200 \mu \mathrm{g} \mathrm{kg}^{-1} \mathrm{LW}$ ) and antibacterial (Bobact ${ }^{\circledR}$ 8, $2.0 \mathrm{~mL} \mathrm{lamb}^{-1}$ ). The lambs adapted to the diets (Table 1) for 10 days and the evaluation time was 56 days. The feed was offered at 07:00 and 15:00 hours and water ad libitum.

\begin{tabular}{|c|c|c|c|c|c|}
\hline Ingredients ( $\left.\mathrm{g} \mathrm{kg}^{-1} \mathrm{DM}\right)$ & $\mathrm{T} 1$ & $\mathrm{~T} 2$ & T3 & $\mathrm{T} 4$ & T5 \\
\hline Urea & 1 & 0.25 & 0.50 & 0.75 & 1 \\
\hline Corn grain & 38 & 41 & 41 & 41 & 41 \\
\hline Bypass fat & 3 & 3 & 3 & 3 & 3 \\
\hline Coconut meal & 18 & 15.75 & 15.50 & 15.25 & 15 \\
\hline Cane molasses & 7 & 7 & 7 & 7 & 7 \\
\hline Mineral premixt & 2 & 2 & 2 & 2 & 2 \\
\hline Calcium carbonate & 1 & 1 & 1 & 1 & 1 \\
\hline Corn silage & 30 & 0 & 0 & 0 & 0 \\
\hline Soy forage & 0 & 30 & 30 & 30 & 30 \\
\hline \multicolumn{6}{|l|}{ Chemical composición (\%) } \\
\hline Dry matter & 61.65 & 95.82 & 94.74 & 93.88 & 93.92 \\
\hline Crude protein & 12.4 & 13.1 & 13.0 & 13.3 & 13.2 \\
\hline Neutral detergent fiber & 25.83 & 23.24 & 25.63 & 24.09 & 27.78 \\
\hline Acid detergent fiber & 13.53 & 14.68 & 16.08 & 14.90 & 18.87 \\
\hline
\end{tabular}

T1: control, T2: 30\% (SF-56 d), T3: 30\% (SF-68 d), T4: 30\% (SF-85 d), T5: 30\% (SF-110 d). ${ }^{\dagger}$ Superbayphos ${ }^{\circledR}$ each 100 g contains: P $10 \%$; Ca $12 \%$; Fe $0.5 \%$; Mg 0.1 \%; Cu $0.15 \%$; Zn $0.12 \%$; Mn 0.055 \%; Co $0.05 \%$; I 0.02 \%; Se 200 ppb; Vitamin A 50000 UI.

\section{Treatments}

Soybean fodder (SF) was manually harvested $(56,68,85$ and 110 days after sowing) in forage banks of that specific species, established in tropical zones. Afterwards it was sun dried on cement floors, and turned over many times during the day in order to get homogeneous drying and avoid fungi growth. Once dried, it was ground in a hammer mill (Azteca, No. 16) with a $1 / 2$ " diameter sieve and then mixed together with the other ingredients in order to make the feed (Table 1). The experimental diets (Table 1) were formulated based on the nutritional requirements for finishing lambs, for a gain of $200 \mathrm{~g} \mathrm{~d}^{-1}$ (NRC, 2007) (Table 1). The treatments evaluated were T1: control, T2: 30\% (SF-56 d), 
T3: 30\% (SF-68 d), T4: 30\% (SF-85 d) and $\mathrm{T} 5 \mathrm{:}$ 30\% (SF-110 d).

During the experimental phase, 3 samples were collected of each experimental diet in order to determine its chemical composition (Table 1); the following were determined: dry matter (DM; method 930.15), ash (method 942.05), crude protein (CP; method 984.13) and ether extract (EE; method 954.02) in accordance to the methodology described by AOAC (2005). The content of neutral detergent fiber (NDF) and acid detergent fiber (ADF) was determined with the method proposed by Van Soest et al. (1991).

\section{Production Variables}

The intake of DM (DMI, $\mathrm{kg} \mathrm{d}^{-1}$ ) was calculated by the difference between the feed offered and the feed rejected each day. Daily weight gain (DWG, $\mathrm{kg} \mathrm{d}^{-1}$ ) was measured by weighing the lambs at the start of the experiment and every 14 days (07:00 h). Feed conversion (FC) was calculated as the DMI/DWG relation.

\section{Experimental Design and Statistical Analysis}

The experimental design was completely random with five treatments and six repetitions per treatment. Data were analyzed with PROC GLM (SAS, 2011) and the treatment averages were compared with the Tukey test $(p<0.05)$.

\section{RESULTS AND DISCUSSION}

Including soybean fodder in different phenological phases in the whole food diet affected $(p<0.05)$ the production behavior variables (DMI, DWG and FC) in the lambs (Table 2). The intake of DM (DMI) in this study was $10.8 \%$ higher in lambs fed with soybean fodder in the diet, compared to the control treatment $(0.87$ vs $0.78 \mathrm{~kg}^{-1} \mathrm{DM} \mathrm{d}^{-1}$ ). It should be noted that at the end of the experimental period, the most DMI was found in lambs that consumed soybean fodder diet at $85 \mathrm{~d}$ of the phenological phase (T4) (Table 2).

The former can be related to the fact that as the lambs weight increases, so does their DMI, due to the higher nutrient requirements and a greater digestive capacity (Pérez-Gil et al., 2011). The nutritional value of soybean fodder in the tropics can be compared to alfalfa in early flowering (Orozco et al., 2015), and in some situations it can be used to replace corn or sorghum grain in the fattening process. On the other hand, soybean fodder meadows can also be grazed or harvested from the flowering phase almost until maturity for its use as high quality hay (Kökten et al., 2014). Reséndiz et al. (2013) evaluated a whole food diet for sheep with 30\% alfalfa, and found a greater DMI (36\%), this difference is attributed to the fact that the lambs used had higher LW (22.1 vs $15.51 \mathrm{~kg}$ ) when compared to the lambs used in the present study. On the other hand, Protes et al. (2018) did not find differences in DMI in lambs fed with silage made from soybean and sorghum fodder. However, Lima et al. (2013) reported higher DM intake in lambs fed with silage made from soybean and sugarcane tips.

In other studies, when up to 30\% Enterolobium cyclocarpum (Fabaceae) was included in the whole food diet for lambs (Peralta et al., 2004; Álvarez et al., 2003), lower DMI values were reported (633 vs. 864 gr) than those in the present study. Similarly, Velázquez et al. (2011) reported lower DMI (620.2 g) when including 10, 20, 30 and $40 \%$ of Acacia farnesiana (Fabaceae) in whole food diets for lambs, which is similar to results in this study when the DMI was $647 \mathrm{~g}$ at 14 days. The differences could be due to different forage contents included in the diet, physiological age and race (Patiño and Van, 2010); also, environmental and management factors could affect the animal response. On the other hand, it could also be attributed to the palatability of the diet, protein content and intake, elevated intake of DM, better digestibility of the diet, and nitrogen use (Obeidat et al., 2020).

Daily weight gain (DWG) of the lambs fed with the whole food diet prepared with soybean fodder is shown in Table 3. As the evaluated days lapsed, the DWG increased, obtaining the highest values at 42 days $\left(0.196 \mathrm{~kg} \mathrm{~d}^{-1}\right)$; however, at the end of the trial period there was a decrease $\left(188 \mathrm{~kg} \mathrm{~d}^{-1}\right)$. This could be due 
to a compensatory growth effect that the lambs could experience because of better nutrition (Patiño and Van, 2010). On the other hand, it could be related to the fact that as the phenological phase of the forage species changes, their nutritional quality is also affected as the regrowth age increases (López and Briceño, 2016), which could result in changes in DWG. These changes were seen in the lambs that consumed diets with soybean fodder at phenological phases of 68 and $85 \mathrm{~d}(0.217$ and $0.214 \mathrm{~kg}$ $\mathrm{d}^{-1}$ ) in comparison to the control group $\left(0.121 \mathrm{~kg} \mathrm{~d}^{-1}\right)$; this effect could be due to higher content of metabolizable energy in soybeans, since the whole plant was used when making the animal feed.

In this sense, Reséndiz et al. (2013) found 30\% higher DWG when evaluating lambs fed with a whole food diet with 30\% alfalfa, compared to the results of this study, which could also be due to higher live weight of the lambs (22.1 vs $15.51 \mathrm{~kg}$ ) compared to those in this study. In other studies, which used Enterolobium cyclocarpum (Fabaceae) pods as supplement for lambs, lower DWG values were reported $\left(0.149 \mathrm{~kg}^{-1} \mathrm{~d}^{-1}\right)$ (Peralta et al., 2004; Álvarez et al., 2003). However, it should be mentioned that even though Creole lambs were used in this study, the DWG obtained were satisfactory for a production system in the tropics. The DWG is consistent with that reported in other studies with lambs fed with diets with high grain content (Vicente-Pérez et al., 2015). It should be noted that the diets used in this study allowed the animals to express their genetic weight gain potential. It is important to point out that the feed conversion
Table 3. Daily weight gain $\left(\mathrm{kg} \mathrm{d}^{-1}\right)$ of lambs fed with a whole food diet elaborated with soybean fodder at different phenological phases.

\begin{tabular}{c|c|c|c|c|c} 
Day & $\mathrm{T} 1$ & $\mathrm{~T} 2$ & $\mathrm{~T}$ & $\mathrm{~T} 4$ & $\mathrm{~T}$ \\
\hline 14 & $0.107^{\mathrm{Cb}}$ & $0.170^{\mathrm{Cab}}$ & $0.245^{\mathrm{Aa}}$ & $0.197^{\mathrm{Bab}}$ & $0.202^{\mathrm{Bab}}$ \\
\hline 28 & $0.120^{\mathrm{Bb}}$ & $0.187^{\mathrm{Aab}}$ & $0.221^{\mathrm{Ba}}$ & $0.219^{\mathrm{ABa}}$ & $0.189^{\mathrm{Bab}}$ \\
\hline 42 & $0.130^{\mathrm{Ab}}$ & $0.193^{\mathrm{Aab}}$ & $0.205^{\mathrm{Ba}}$ & $0.223^{\mathrm{Aa}}$ & $0.231^{\mathrm{Aa}}$ \\
\hline 56 & $0.130^{\mathrm{Ab}}$ & $0.181^{\mathrm{Bab}}$ & $0.199^{\mathrm{Ba}}$ & $0.219^{\mathrm{ABa}}$ & $0.211^{\mathrm{Ba}}$ \\
\hline
\end{tabular}

T1: control, T2: 30\% (SF-56 d), T3: 30\% (SF-68 d), T4: 30\% (SF-85 d), T5: 30\% (SF-110 d). $a, b, c$ Means with different letters in a row are different (Tukey; $p \leq 0.05$ ); A,B,C Means with different letters in a column are different ( $p \leq 0.05)$.

\begin{tabular}{|c|c|c|c|c|c|}
\hline Day & T1 & T2 & T3 & T4 & T5 \\
\hline 14 & $6.070^{\mathrm{Ca}}$ & $4.910^{\mathrm{Bab}}$ & $3.100^{\mathrm{Db}}$ & $3.490^{\mathrm{Bb}}$ & $3.060^{\mathrm{Bb}}$ \\
\hline 28 & $5.870^{\mathrm{Ca}}$ & $4.660^{\mathrm{Cab}}$ & $3.950^{\mathrm{Cb}}$ & $4.110^{\mathrm{Bb}}$ & $4.980^{\mathrm{Aab}}$ \\
\hline 42 & $6.640^{\mathrm{Aa}}$ & $5.120^{\mathrm{Bb}}$ & $4.451^{\mathrm{Bb}}$ & $4.293^{\mathrm{ABb}}$ & $4.301^{\mathrm{Ab}}$ \\
\hline 56 & $6.590^{\mathrm{ABa}}$ & $5.760^{A b}$ & $5.150^{\mathrm{Ab}}$ & $5.010^{\mathrm{Ab}}$ & $4.750^{\mathrm{Ab}}$ \\
\hline
\end{tabular}

T1: control, T2: 30\% (SF-56 d), T3: 30\% (SF-68 d), T4: 30\% (SF-85 d), T5: 30\% (SF-110 d). $a, b, c$ Means with different letters in a row are different (Tukey; $\mathrm{P} \leq 0.05$ ); $A, B, C$ Means with different letters in a column are different $(p \leq 0.05)$

(FC) reported here was $41 \%$ lower in animals that received the diet made with soybean fodder (FC; 4.44), compared to animals in the control group (FC; 6.29). Protes et al. (2018) reported a FC of 3.9 in lambs fed with $35 \%$ soybean fodder silage; in contrast, Lima et al. (2013) found higher values (6.17) in lambs fed with $30 \%$ soy silage. This productive response could be due to better nutrient utilization when soybean fodder is added at 68 days after sowing

\section{CONCLUSIONS}

Adding $30 \%$ of soybean fodder at 68 days after sowing to the whole food diet improved the productive behavior of the lambs, because it increased the daily weight gain and optimized the food conversion as a result of more efficient nutrient use.

\section{REFERENCES}

Álvarez, M.G., Melgarejo, V.L., \& Castañeda, N.Y. (2003). Ganancia de peso, conversión y eficiencia alimenticia en ovinos alimentados con fruto (semilla con vaina) de parota (Enterolobium cyclocarpum) y pollinaza. Veterinaria México 34: 39-46.

AOAC (2005). Official methods of analysis, 18th edition AOAC, Washington: Association of Official Analytical Chemists.

Clavero, T. (2013). Agroforestería en la alimentación de rumiantes en América Tropical. Revista de la Universidad del Zulia 3ạ. Época Ciencias del Agro, Ingeniería y Tecnología 2: 11-35.

CONAGUA (2019). Información climatológica por estado: Guerrero. https://smn.conagua.gob. $\mathrm{mx} / \mathrm{es} /$ informacion-climatologica-por-estado?estado=gro

Delgado, D.C., Hera, R., Cairo, J., \& Orta, Y. (2014). Samanea saman, árbol multipropósito con potencialidades como alimento alternativo para animales de interés productivo. Revista Cubana de Ciencia Agrícola 48: 205-212

Dias, O.R., da Silva, C.M., Mielezrski, F., Bezerra, L.J.S., \& Loiola, E.R. (2016). Harvest growth stages in soybean cultivars intended for silage. Acta Scientiarum. Animal Sciences 38 . $383-387$. 
Garcia, D.E., Medina, M.G., Cova, L.J., Soca, M., Pizzani, P., Baldizán, A. \& Dominguez, C.E. (2008). Aceptabilidad de follajes arbóreos tropicales por vacunos, ovinos y caprinos en el estado Trujillo. Venezuela. Zootecnia Tropical 26:191-196.

Khan, M.I., Jo, C., \& Tariq, M.R. (2015). Meat flavor precursors and factors influencing flavor precursors-A systematic review. Meat Science 110: 278-284.

Kökten, K., Seydosoglu, S., Kaplan, M., \& Boydak, E. (2014). Forage nutritive value of soybean varieties. Legume Research 37: 201-206.

Lima, J.A., de Campos, G. I.L., Pacheco, B.C.M., Berndt, A., de Andrade G.F.M., de Paro, P.C.C., da Cunha, E.A. (2013). Soybean silage and sugarcane tops silage on lamb performance. Ciencia Rural 43: 1478-1484.

López, H. M., \& Briceño, A. E. (2016). Efecto de la frecuencia de corte y la precipitación en el rendimiento de Cratylia argentea orgánica. Nutrición Animal Tropical 10(1): 24-44.

NRC (2007). Nutrient Requirements of Small Ruminants: Sheep, Goats, Cervids and New World Camelids. The National Academy Press. Washington, DC. USA. 362 p.

Obeidat, B.S., Subih, H.S., \& Ata, M. (2020). Protein supplementation improves performance of lambs fed low-quality forage. Animals 10(51): 1-7.

Orozco, H.G., Retana, S.D.G., Quiroga, G. M. H. \& Nava R.P. (2015) Potencial forrajero de variedades de soya pertenecientes a diferentes grupos de madurez en Delicias, Chihuahua AGROFAZ 15: 83-93.

Palma, J.M. (2005). Los árboles en la ganadería del trópico seco. Avances en Investigación Agropecuaria 1: 1-11.

Partida, P.J.A., Braña, V.D., Jiménez, S.H., Ríos, R.F.G., \& Buendía, R.G. (2013). Producción de carne ovina. Libro técnico No.5. 107 p.

Patiño, P.R., \& Van, C.E. (2010). Aspectos chave do crescimento em ovinos. Revista Colombiana de Ciencia Animal 2: 399-421.

Peralta, N., Palma, J.M., \& Macedo, R. (2004). Efecto de diferentes niveles de inclusión de parota (Enterolobium cyclocarpum) en el desarrollo de ovinos en estabulación. Livestock Research for Rural Development 16 (1).

Pérez-Gil, R.F., Carranco, J.M.E., Calvo, C.M.C., Solano, L., \& Martínez, I.T.J. (2014). Caracterización química de panojas y vainas con semillas nativas del estado de Guerrero, México, para uso en la alimentación animal. Revista Mexicana de Ciencias Pecuarias 5: 307-319.

Pirela, M.F., Perozo, B.A., Montero, U.M., Contreras, M.G., Valbuena, C.E., \& Zambrano, N.S. (2010). Producción y calidad de la leche de vacas Criollo Limonero suplementadas con harina de frutos de samán [Pithecellobium saman (Jacq) Benth]. Revista de la Facultad de Agronomía de la Universidad de Zulia 27: 607-625.
Protes, V.M., Costa, C., Pariz, C.M., Castilhos, A.M., Meirelles, P.R.L., Longhini, V.Z., Roca, R.O., Ricardo, H.A., \& Melo, V.F.P. (2018). Effects of soybean silage on feeding behavior, performance, and meat quality of lambs. Small Ruminant Research 164: 64-69.

Reséndiz, C.V., Hernández, O., Guerrero, I., Gallegos, J., Martínez, P.A., \& Sánchez, C. (2013). Engorda de corderos Pelibuey con diferente nivel de alfalfa en la dieta. Archivos de Zootecnia 62: 457-467.

Rigueira, S.J.P., Gomes, P.O., Valadares, F.S.C., Guimarães, R.K., Garcia, R., \& Santos, C.A. (2015). Soybean silage in the diet for beef cattle. Acta Scientiarum. Animal Sciences 37: 61-65.

SAS (2011). SAS/STAT Sofware. Versión 9.3. Cary, NC SAS, USA: SAS Institute INC.

Tobía, C., \& Villalobos, E. (2004). Producción y valor nutricional del forraje de soya en condiciones tropicales adversas. Agronomía Costarricense 28: 17-25.

Tobía, C., Villalobos, E., \& Rico, E. (2006). Uso del forraje de soya (Glycine max L. Merr.) variedad Cigras 06 en la nutrición de los rumiantes. X Seminario de Pastos y Forrajes 77-86.

Van Soest, P. J., Robertson, J. B., \& Lewis, B. A. (1991). Methods for Dietary Fiber, Neutral Detergent Fiber, and Non starch Polysaccharides in Relation to Animal Nutrition. Journal of Dairy Science 74:3583-3597.

Vargas-Bello-Pérez, E., Mustafa, A.F., Seguin, P., 2008. Effects of feeding forage soybean silage on milk production, nutrient digestion, and ruminal fermentation of lactating dairy cows. Journal of Dairy Science 91, 229-235

Vélez, A., Espinosa, J.A., De la Cruz, L., Rangel, J., Espinosa, I., \& Barba, C. (2016). Caracterización de la producción de ovino de carne del estado de Hidalgo, México. Archivos de Zootecnia 65: $425-428$.

Velásquez, A.J., González, M., Perezgrovas, R., Bórquez, J. y Domínguez, I. (2011). Producción, digestibilidad y rentabilidad en corderos de dietas con vainas de Acacia farnesiana. Archivos de Zootecnia 60: 479-488.

Vicente-Pérez, R., Avendaño-Reyes, L., Álvarez, F.D., Correa-Calderón, A., Meza-Herrera, C.A., Mellado, M., Quintero, J.A., \& MacíasCruz, U. (2015). Comportamiento productivo, consumo de nutrientes y productividad al parto de ovejas de pelo suplementadas con energía en el preparto durante verano e invierno. Archivos de Medicina Veterinaria 47: 301-309.

Zamora, S., García, J., Bonilla, G., Aguilar, H., Harvey, C. A., \& Ibrahim, M. (2001). ¿Cómo utilizar los frutos de guanacaste (Enterolobium cyclocarpum), guácimo (Guazuma ulmifolia), genizaro (Pithecellobium saman) y jícaro (Crescentia alata) en alimentación animal?. Agroforestería en las Américas 8: 45-49. 